\title{
TRIGLYCERIDE COMPOSITION OF SIXTEEN STRAINS OF MARINE DIATOM
}

\author{
Lily M.G. Panggabean ${ }^{1}$, Abdullah Rasyid ${ }^{1}$, Zarrah Duniani ${ }^{2}$, Yana Meliana ${ }^{2}$, dan \\ Indah Kurniasih ${ }^{2}$ \\ ${ }^{1}$ Bidang Sumberdaya Hayati Laut, Pusat Penelitian Oseanografi-LIPI, Ancol-Jakarta \\ Email:mglilyp@yahoo.com \\ ${ }^{2}$ R\&D PERTAMINA, Pulo Gadung-Jakarta
}

\begin{abstract}
S
Trigliceride or triacylglicerol (TAG) composition in crude oil of sixteen strain of marine diatom has been detected by spectra analyses on an Electrospray - Ion Trap - Mass Spectrometry (ESIIT-MS) HCT Bruker-Daltonic GmbH instrument with AgNO3 used as coordination ionization agent. Biomass samples of each microalga strain were taken from early and late stationary cultures in $\mathrm{f} / 2$ enriched seawater and algal oils were extracted according to Bligh and Dyer. Results from spectra analysis showed that P-Pt-P $\left(\mathrm{C}_{16: 0}-\mathrm{C}_{16: 1}-\mathrm{C}_{16: 0}\right)$ were distinguished in TAG from diatom strains Chaetoceros sp.1, Chaetoceros sp.2, Thalasiossira sp.1, Thalasiossira sp.2, Thalasiossira sp.3, Navicula sp. 1, Navicula sp. 2, Navicula sp. 3, Navicula sp. 4, Nitzschia sp. 2 and Amphora sp. In contrast, TAGs in Melosira sp. included P-P-P $\left(\mathrm{C}_{16: 0}-\mathrm{C}_{16: 0}-\mathrm{C}_{16: 0}\right)$ and P-P-O $\left(\mathrm{C}_{16: 0}-\mathrm{C}_{16: 0}-\mathrm{C}_{18: 1}\right)$ were identified. TAGs from Chaetoceros sp. were the most varies among samples, i.e. P-Pt-P $\left(\mathrm{C}_{16: 0}-\mathrm{C}_{16: 1} \mathrm{C}_{16: 0}\right)$, A-P-M $\left(\mathrm{C}_{20: 4}-\mathrm{C}_{16: 0}-\mathrm{C}_{14: 0}\right)$, P-Pt-Lt $\left(\mathrm{C}_{16: 0}-\mathrm{C}_{16: 1}-\mathrm{C}_{18: 3}\right)$, P-PtA $\left(\mathrm{C}_{16: 0} \mathrm{C}_{16: 1}-\mathrm{C}_{20: 4}\right)$, D-P-P $\left(\mathrm{C}_{22: 6}-\mathrm{C}_{16: 0}-\mathrm{C}_{16: 0}\right)$, A-Ln-P $\left(\mathrm{C}_{20: 4}-\mathrm{C}_{18: 2}-\mathrm{C}_{16: 0}\right)$. Various TAGs were also detected in Nitzschia sp.2, i.e. P-Pt-M $\left(\mathrm{C}_{16: 0}-\mathrm{C}_{16: 1} \mathrm{C}_{14: 0}\right)$, P-Pt-P $\left(\mathrm{C}_{16: 0} \mathrm{C}_{16: 1}-\mathrm{C}_{16: 0}\right)$, P-Pt-S $\left(\mathrm{C}_{16: 0}-\mathrm{C}_{16: 1}-\mathrm{C}_{18: 0}\right)$, P-Pt-A $\left(\mathrm{C}_{16: 0}-\mathrm{C}_{16: 1}-\mathrm{C}_{20: 4}\right)$. TAGs composition in Skeletonema strains that similar to those in Nitzschia sp.1 has longer carbon, i.e. P-P-O $\left(\mathrm{C}_{16: 0^{-}} \mathrm{C}_{16: 0^{-}} \mathrm{C}_{18: 1}\right), \mathrm{P}-\mathrm{O}-\mathrm{O}\left(\mathrm{C}_{16: 0^{-}}\right.$ $\left.\mathrm{C}_{18: 1}-\mathrm{C}_{18: 1}\right)$ and O-O-O $\left(\mathrm{C}_{18: 1}-\mathrm{C}_{18: 1}-\mathrm{C}_{18: 1}\right)$. TAGs with longer carbon chain and more double bond including highly unsaturated fatty acid $\mathrm{C}_{20: 4}$ were increased with culture age in diatoms Chaetoceros sp.1, Chaetoceros sp.2, Thalasiossira sp.2, Navicula sp.1 and Nitzschia sp. 2.
\end{abstract}

Keywords: diatom, TAG, ESI-IT-MS, f/2, early and late stationary

\section{INTRODUCTION}

Nowadays development of microalgae as a source of fuel to substitute future fossil fuel crisis have attracted attention worldwide (Benneman, 2008; Patil et al., 2008; Chisti, 2007; Guschina and Harwood, 2006; NREL, 2005). The interest in microalgae, for alternative second generation biofuel sources, is less competitive with food and feed production. Aquatic Species Program supported by the U.S. Department of Energy (DOE) has collected over 3000 algal strains and screened for their oils as renewable source of biodiesel. Biodiesel from algae contains no sulfur, nontoxic and highly biodegradable. There were 300 species of green and diatoms algae reported by DOE as promising strains for development of biofuel. Panggabean et al. (2009) and Bayu et al. (2009) also reported some native Indonesian diatoms to be potential renewable feedstocks. Those findings were based on their capabilities for oil production.

Diatoms (Bacillariophyta) are greatly diverse and abundant as the green algae, including 285 genera (Round et al., 1990). Diatoms belong to Ochrophytes based on the presence of golden brown (ocher) fucoxanthin besides chlorophyll a and c, chrysolaminarin and the silicious cell coverage -the frustule- of various ornamentation which reflecting taxonomic diversity. Their existance is very important to contribute global primary productivity in oceans, lake and various 
environments. They live as planktonic, benthic, periphytic (on plant leave or seaweed surfaces), epizoic (on crustaceans, whales etc.), endozoic (within foraminifera), moist teresstrial habitats, polar ice etc. Several diatom strains of Indonesian waters are maintained in the culture collection of Research Centre for Oceanography, Indonesian Institute of Science.

Diatoms store carbon in the form of natural oils or as polymer of carbohydrates known as chrysolaminarin. The natural oils from diatoms and algae are in the form of triacylglycerols (TAGs). TAGs consist of three long chains of fatty acids attached to a glycerol backbone. TAGs with methanol through transesterification reaction a chemical compound known as an alkyl ester or generically known as biodiesel. Biodiesel is an alternative to petroleum diesel fuel. The fatty acids components of different microalgal strains determine the fuel produced, because individual fatty acid chains is species or strain specific (Pernet et al., 2003; Hu et al., 2008). TAG content and variation could be change as they grow or at different physiological condition. Therefore variations in fatty acids component in algal lipid would be necessary to take into consideration. The objective of this present study is to determine fatty acids components of TAG of typical diatom strains from two stages of culture.

\section{METHOD}

Sixteen strains of marine diatoms (Table 1) originally taken from microalgal culture collection of Research Centre for Oceanography, LIPI, were used in the experiment. Several group of algal strains were cultured during February through March 2012 and others were cultured during May though June 2012 in our laboratory. Each strain were grown in two
1L seawater with salinity of 27ppt enriched with f/2 media (Guillard, 1975). The cultures were aerated and incubated in air condition room $\left(23-25{ }^{\circ} \mathrm{C}\right)$ under 3000 lux illumination for $12 \mathrm{hrs} / \mathrm{day}$. At early and late stationary phases, $50 \mathrm{~mL}$ cultures were filtered through GF/F membrane for biomass measurement and $300 \mathrm{~mL}$ of culture stock for algal oils extraction according to method of Bligh and Dyer (1959) using chloroform : methanol Proportion. The TAG components of the algae oil were analyzed by electron spray ionization-ion trap-mass spectrometry (ESI-IT-MS) on HCT Brucker-Daltonic GmBH instruments with $\mathrm{AgNO}_{3}$ used as coordination ionization agent (Sandra et al., 2002)

\section{RESULT AND DISCUSSION}

\subsection{Biomass and Lipid Production}

Biomass obtained from early stationary phase were varied from 142 $\mathrm{mg} / \mathrm{L}$ for Amphora sp. to $698 \mathrm{mg} / \mathrm{L}$ for Skeletonema sp. 1. Biomass were mostly increased from early to late stationary phase up to $880 \mathrm{mg} / \mathrm{L}$ in Skeletonema sp. 3 (Figure 1) and the increment was greatest for Amphora sp. (> 200\%). However lipid content which expresses as dry weight/ L (Figure 1) or percentage of biomass dry weight did not follow biomass production rate (Figure 2). The strain Skeletonema sp.1, Skeletonema sp. 2, Nitzschia sp. 1, Thalassiosira sp. 1 and Thalassiosira sp. 3 have high biomass production rates, but low lipid content. On the other hand those algae with lower biomass dry weight (Chaetoceros, Melosira, Navicula and Amphora) produced higher lipid content. Lipid content varied from $1.39 \%$ in Thalassiosira sp. 3 to $26 \%$ in Amphora sp. after reaching early stationary phase and from $0.76 \%$ in Skeletonema sp. 1 to $20 \%$ in Chaetoceros sp. 1 after late stationary phase. Lipid accumulation 
during stationary phase was observed in most of centric diatoms (Chaetoceros, Melosira sp., Skeletonema sp. 3 and Thalassiosira) (Figure 2) which also reported in several literatures (Bayu et al., 2010; Nurachman et al., 2012 b, Panggabean et al., 2009; Pratiwi et al., 2009). Highest lipid accumulation was observed in Melosira sp., that was up to 4.5 fold from the early stationary harvest. It was in contrary with the naviculoids or pennate diatoms (Navicula, Nitzschia and Amphora), further culturing to late stationary phase did not increase but decreased their lipid content. Top lipid producer are Chaetoceros sp. 1 (20\%) and Amphora sp. (26\%) that represented the centrics and naviculoids repectively among our samples examined. Those percentage were derived from 38.2 and $30.8 \mathrm{mg} / \mathrm{L}$ lipid product from Chaetoceros sp.1 and Amphora sp respectively. Higher lipid product was resulted from Thalassiosira sp. $2(65.78 \mathrm{mg} / \mathrm{L})$ which only $15 \%$ of its high biomass yield. Moderate lipid contents includes Melosira sp. (18\%) from the centrics and Navicula sp. (17-22\%) from the naviculoids were derived from $49 \mathrm{mg} / \mathrm{L}$ and 35-43 mg/L lipid respectively. Earlier lipid accumulation also observed in the Navicula sp. of Nurachman et al. (2012b). Thus the use of the naviculoids may be more economical in terms shorter culture biomass production. Achievable yield of about $142-880 \mathrm{mg} / \mathrm{L}$ biomass with $1-26 \%$ oil content (as triglycerides) in this study was lower than our former results (Bayu et al., 2010; Nurachman et al., 2012 a and b, Panggabean et al., 2012). The low TAG production was due to different culture conditions, i.e. lower temperature and light intensity. Low light intensity favours the formation of the membrane polar lipid associated with chloroplast (Brown et al., 1996, Orcutt and Patterson, 1974, Sukenik et al., 1989).

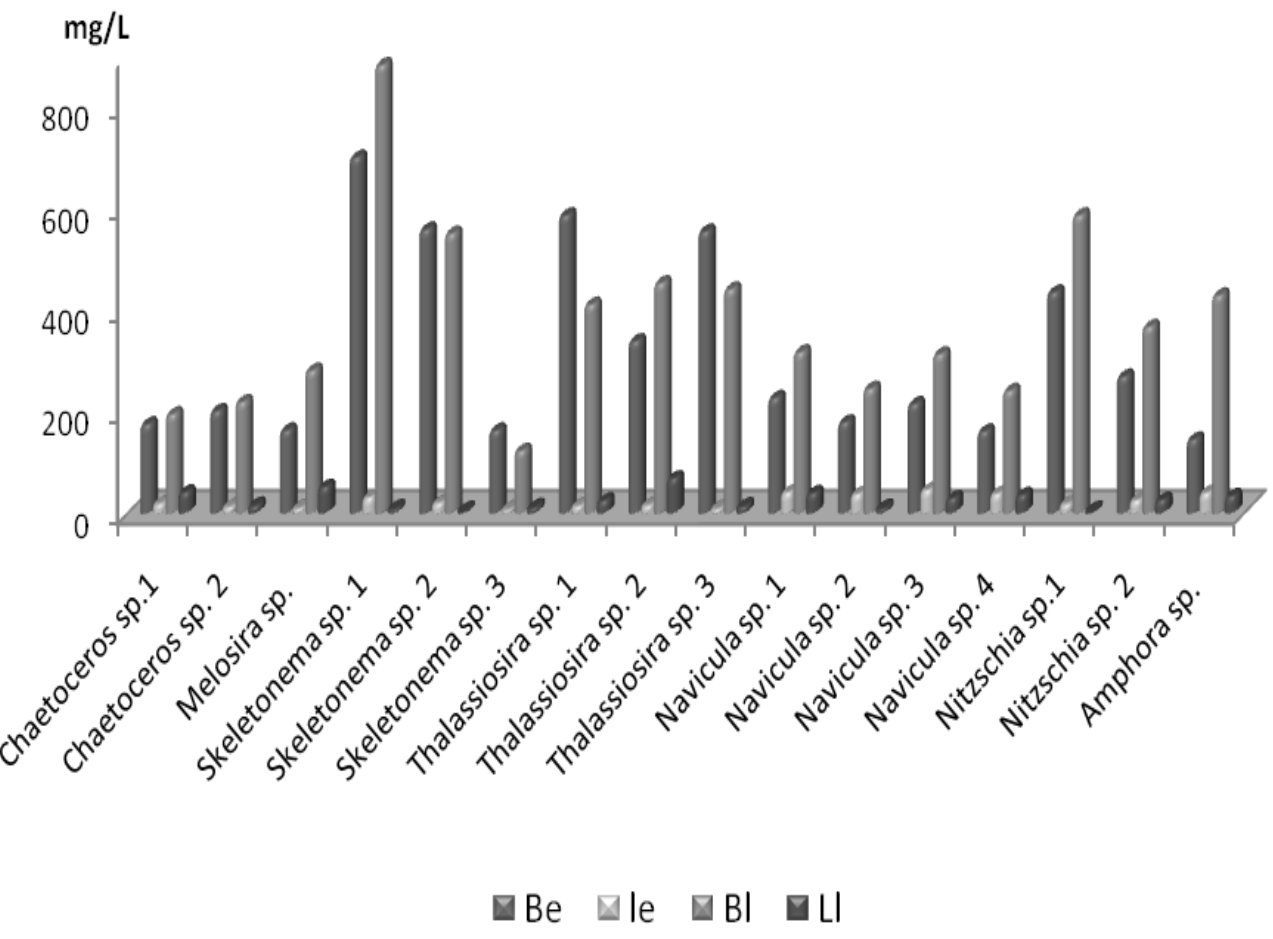

Figure 1. Biomass and lipid (mg/L dry weight) yield of sixteen diatom strains from early (Be and $\mathrm{Le}$ ) and late (Bl and $\mathrm{Ll}$ ) stationary phase. 


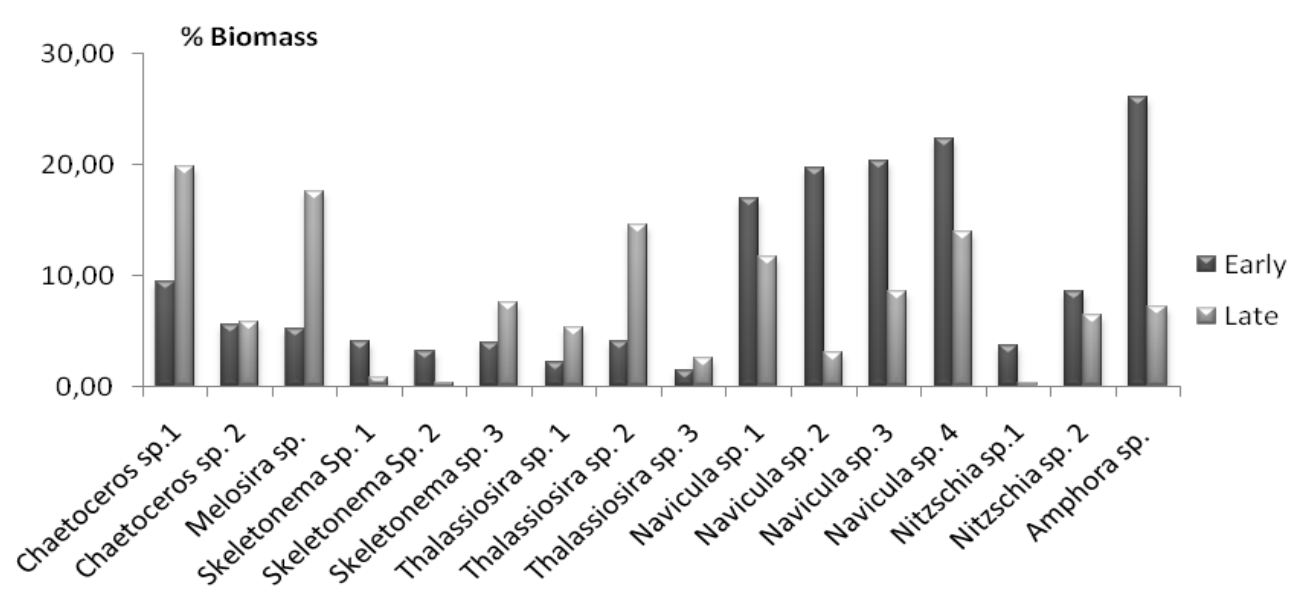

Figure 2. Lipid content (\% biomass) of sixteen diatom strains from early and late stationary phase.

\subsection{Fatty Acids Composition}

Fatty acids are building blocks for the formation of various types of lipids, which may include neutral lipids, polar lipids, wax esters, sterols, hydrocarbons and derivates prenyl e.g. carotenoids and phytylated pyrrole chlorophyls (Hu et al., 2008). Lipid from growing algae are mostly membrane polar glycerol-based lipids, which constitute about $5-20 \%$ of dry weight. Under stress condition, they shift their membrane lipids into storage neutral lipids in the form of triacyl glycerol (TAG) (Brown et al., 1993; Grimma et al., 1992; Parish and Wangersky, 1987, 1990; Lombardi and Wangersky, 1991,1995; Leonardos and Geider, 2004; McGinnis et al., 1997).

Component of fatty acids are either saturated or unsaturated with double bonds on the carbon chain backbone. They are classified into medium chain C10-C14; long chain C16-C18 and very long $\geq$ C20 species fatty acids and derivatives (Hu et al., 2008). Fatty acid composition of lipid alga is species or strain specific and varies with different culture conditions (Guschina and Harwood, 2006; Chisti, 2009).

The analysis of fatty acid composition in this study was conducting using the total lipid extracts rather than examining individual lipid classes. The results showed that TAGs in most diatom strains (Bacillariophyta) consisted of longchain $\mathrm{C}_{16}$ fatty acids (Table 1 ). The $\mathrm{C}_{16}$ component in Chaetoceros sp.1, Chaetoceros sp.2, Thalasiossira sp.1, Thalasiossira sp.2, Thalasiossira sp.3, Navicula sp. 1, Navicula sp. 2, Navicula sp. 3, Navicula sp. 4, Nitzschia sp. 2 and Amphora sp. were predominated by saturated and mono-unsaturated P-Pt-P $\left(\mathrm{C}_{16: 0}-\mathrm{C}_{16: 1}-\mathrm{C}_{16: 0}\right)$, but in Melosira sp. was predominated by saturated P-P-P $\left(\mathrm{C}_{16: 0^{-}}\right.$ $\left.\mathrm{C}_{16: 0}-\mathrm{C}_{16: 0}\right)$. Other TAG species from Melosira sp., also contained longer $\mathrm{C}_{18}$ mono-saturated fatty acid P-P-O $\left(\mathrm{C}_{16: 0^{-}}\right.$ $\mathrm{C}_{16: 0}-\mathrm{C}_{18: 1}$ ) also occured. TAGs species from Skeletonema and Nitzschia sp.1 are mostly contained $\mathrm{C}_{18}$ carbon chains, i.e. PP-O (C $\left.\mathrm{C}_{16: 0}-\mathrm{C}_{16: 0}-\mathrm{C}_{18: 1}\right)$, P-O-O ( $\mathrm{C}_{16: 0^{-}}-\mathrm{C}_{18: 1^{-}}$ $\left.\mathrm{C}_{18: 1}\right)$ and O-O-O ( $\left.\mathrm{C}_{18: 1}-\mathrm{C}_{18: 1}-\mathrm{C}_{18: 1}\right)$. On the other hand, the chain length in Nitzschia sp. 2 varied from $\mathrm{C}_{14}-\mathrm{C}_{20}$, i.e. PPt-M $\quad\left(\mathrm{C}_{16: 0^{-}}-\mathrm{C}_{16: 1}-\mathrm{C}_{14: 0}\right)$, P-Pt-P $\quad\left(\mathrm{C}_{16: 0^{-}}\right.$ $\left.\mathrm{C}_{16: 1}-\mathrm{C}_{16: 0}\right)$, P-Pt-S ( $\left.\mathrm{C}_{16: 0}-\mathrm{C}_{16: 1}-\mathrm{C}_{18: 0}\right)$, PPt-A ( $\left.\mathrm{C}_{16: 0}-\mathrm{C}_{16: 1}-\mathrm{C}_{20: 4}\right)$.

Variation in chain length and degree of saturation in Chaetoceros sp.1 oils are much greater than those in the other diatoms, which were particularly detected from the early stationary phase specimens, namely from medium-chain 
$\mathrm{C}_{14}$ saturated to very-long-chain $\mathrm{C}_{20-22}$ poly-unsaturated fatty acids (PUFA) or highly-unsaturated fatty acids (HUFA). TAGs detected in Chaetoceros sp.1. are

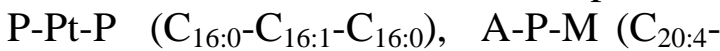
$\left.\mathrm{C}_{16: 0}-\mathrm{C}_{14: 0}\right)$, P-Pt-Lt $\left(\mathrm{C}_{16: 0}-\mathrm{C}_{16: 1}-\mathrm{C}_{18: 3}\right)$, PPt-A (C $\left.16: 0-\mathrm{C}_{16: 1}-\mathrm{C}_{20: 4}\right)$, D-P-P (C $\mathrm{C}_{22: 6^{-}}$ $\left.\mathrm{C}_{16: 0}-\mathrm{C}_{16: 0}\right)$, A-Ln-P $\left(\mathrm{C}_{20: 4}-\mathrm{C}_{18: 2}-\mathrm{C}_{16: 0}\right)$ The very long PUFA above $\mathrm{C}_{18}$ is typical marine algae which can not be synthesized by higher plants (Hu et al., 2008).

TAGs with very-long-chain HUFA $\mathrm{C}_{20: 4}$ in Chaetoceros sp.1, Chaetoceros sp.2, Thalasiossira sp.2, Navicula sp.1, and Nitzschia sp. 2 increased during late stationary phase, which also observed in other diatoms (Hatate et al., 1998; Chrismada et al., 1993; Bayu et al., 2009; Tonon, 2002). The oils of high PUFA contents are not stable and more susceptible to oxidation during storage which not suitable for diesel fuel, according to EU standard requirement EN 14214 and EN 14213 (Chisti, 2007). With the current technology, i.e. partial catalytic hydrogenations of the oil, the unsaturation of more than four double bonds can be reduced (Jay et al. 2005; Dijkstra 2006 cited by Chisti, 2007).

Table 1. Triacyl glycerol from sixteen strains of diatoms.

\begin{tabular}{|c|c|c|c|}
\hline No. & Strain Name & $\begin{array}{l}\text { Specimens from early stationary } \\
\text { phase }\end{array}$ & $\begin{array}{l}\begin{array}{l}\text { Specimens from late stationary } \\
\text { phase }\end{array} \\
\end{array}$ \\
\hline \multirow[t]{6}{*}{1} & Chaetoceros sp.1 & P-Pt-P （C16:0-C16:1-C16:0) & P-Pt-P （C16:0-C16:1-C16:0) \\
\hline & & A-P-M (C20:4-C16:0-C14:0) & P-Pt-A (C16:0-C16:1-C20:4) \\
\hline & & P-Pt-Lt (C16:0-C16:1-C18:3) & P-Ln-P (C16:0-C18:2-C16:0) \\
\hline & & P-Pt-A (C16:0-C16:1-C20:4) & \\
\hline & & D-P-P $\quad$ (C22:6-C16:0-C16:0) & \\
\hline & & A-Ln-P (C20:4-C18:2-C16:0) & \\
\hline \multirow[t]{2}{*}{2} & Chaetoceros Sp. 2. & P-Pt-P $\quad$ (C16:0-C16:1-C16:0) & (C16:0-C20:4-C16:0) \\
\hline & & (C18:0-C16:1-C16:0) & \\
\hline \multirow[t]{2}{*}{3} & Melosira sp. & (C16:0-C16:0-C16:0) & nd \\
\hline & & (C16:0-C16:0-C18:1) & \\
\hline \multirow[t]{3}{*}{4} & Skeletonema sp. 1. & nd & P-P-O $\quad(\mathrm{C} 16: 0-\mathrm{C} 16: 0-\mathrm{C} 18: 1)$ \\
\hline & & & P-O-O $\quad$ (C16:0-C18:1-C18:1) \\
\hline & & & S-Ln-S (C18:0-C18:2-C18:0) \\
\hline \multirow[t]{2}{*}{5} & Skeletonema sp. 2. & (C16:0-C16:0-C18:1) & nd \\
\hline & & (C16:0-C18:1-C18:1) & \\
\hline \multirow[t]{2}{*}{6} & Skeletonema sp. 3. & (C16:0-C18:1-C18:1) & nd \\
\hline & & O-O-O (C18:1-C18:1-C18:1) & \\
\hline 7 & Thalasiossira sp.1. & P-Pt-P $\quad$ (C16:0-C16:1-C16:0) & nd \\
\hline \multirow[t]{4}{*}{8} & Thalasiossira sp.2. & P-Pt-P $\quad$ (C16:0-C16:1-C16:0) & P-Pt-P $\quad$ (C16:0-C16:1-C16:0) \\
\hline & & P-Pt-A (C16:0-C16:1-C20:4) & A-P-M (C20:4-C16:0-C14:0) \\
\hline & & & P-Pt-Lt (C16:0-C16:1-C18:3) \\
\hline & & & P-Pt-A (C16:0-C16:1-C20:4) \\
\hline \multirow[t]{2}{*}{9} & Thalasiossira sp.3. & (C16:0-C16:1-C16:0) & P-Pt-P $\quad$ (C16:0-C16:1-C16:0) \\
\hline & & & P-Pt-O (C16:0-C16:1-C18:1) \\
\hline \multirow[t]{2}{*}{10} & Navicula sp. 1. & (C16:0-C16:1-C16:0) & P-Pt-P $\quad$ (C16:0-C16:1-C16:0) \\
\hline & & & P-Pt-A (C16:0-C16:1-C20:4) \\
\hline 11 & Navicula sp. 2. & nd & P-Pt-P $\quad$ (C16:0-C16:1-C16:0) \\
\hline \multirow[t]{2}{*}{12} & Navicula sp. 3. & (C16:0-C16:1-C16:0) & (C16:0-C16:1-C16:0) \\
\hline & & (C18:0-C16:1-C16:0) & (C16:0-C16:1-C18:0) \\
\hline 13 & Navicula sp .4. & nd & (C16:0-C16:1-C16:0) \\
\hline \multirow[t]{2}{*}{14} & Nitzschia sp.1. & (C16:0-C16:0-C18:1) & P-O-O $\quad(\mathrm{C} 16: 0-\mathrm{C} 18: 1-\mathrm{C} 18: 1)$ \\
\hline & & O-S-O (C18:1-C18:0-C18:1) & O-O-O (C18:1-C18:1-C18:1) \\
\hline \multirow[t]{4}{*}{15} & Nitzschia sp. 2. & P-Pt-M (C16:0-C16:1-C14:0) & P-Pt-A (C16:0-C16:1-C20:4) \\
\hline & & P-Pt-P (C16:0-C16:1-C16:0) & \\
\hline & & P-Pt-S (C16:0-C16:1-C18:0) & \\
\hline & & P-Pt-A (C16:0-C16:1-C20:4) & \\
\hline \multirow[t]{2}{*}{16} & Amphora sp. & P-Pt-P (C16:0-C16:1-C16:0) & nd \\
\hline & & Ln-P-P (C18:2-C16:0-C16:0) & \\
\hline
\end{tabular}




\section{CONCLUSION}

Tags in the diatom studied were mostly contained long chain $\mathrm{C}_{16}$ saturated and mono-saturated fatty acid. Longer $\mathrm{C}_{18}$ fatty acids also occurred in chain forming diatom Melosira, Skeletonema costatum and Nitzschia sp.1. Very long PUFA above $\mathrm{C}_{18}$ was observed from Chaetoceros, Thalassiosira, Navicula and Nitzschia sp.2. The unsaturation was increased during stationary phase.

\section{REFERENCES}

Bayu, A., L.M.G. Panggabean, D.R.N. Noerdjito, and Afdal. 2010. Fatty acid composition of some Indonesian marine microalgal collected in Research Centre For Oceanography, Indonesian Institute of Sciences. Proceeding National Seminar on Seaweed and Minisymposium on Microalgae II, Jakarta 22-23 June 2010. 227238pp.

Bayu, A., L.M.G. Panggabean, and D.R. Noerdjito. 2009. Screening for lipid content of marine mikroalga of Indonesia as a source for biodiesel. Proceeding National Scientific Forum Year VI, Indonesian Oceanolog Association (ISOI), Bogor, November 2009. 175-181pp.

Bligh, E.G. and W.J. Dyer. 1959. A rapid method of total lipid extraction and purification. Canadian J. of Biochemistry and Pysiology, 37:911-917.

Brown, M.R., C.A. Dunstan, and S.W. Jeffrey. 1993. The influence of irradiance on the biochemical composition of the primnesiophyte Isochrysis sp. (clone T-ISO). J. of Phycology, 29:601-612.

Chrismadha, T. 1993. Growth and chemical composition of a diatom
Phaeodactylum tricornutum Bohlin in a tubular photobioreactor. Oseanologi dan Limnologi di Indonesia, 27:33-45.

Grimma, E.M., F.G. Camacho, F.A. Sanchez Perez, and J.L. Gracia Sanchez. 1992. Biochemical productivity of Isochrysis galbana Parke and Tetraselmis sp., as a function of incident light intensity. Process Biochemistry, 29:119-126.

Guillard, R.R.L. 1975. Culture of phytoplankton for feeding marine invertebrates. In: Smith, W.L. and M.H. Chanley (eds.). Culture of Marine Invertebrate Animals. Plenum Press. New York. 2660pp.

Guschina, I.A. and J.I. Harwood. 2006. Lipids and lipid metabolism in eukaryotic algae. Progress Lipid Research, 45:160-186.

Hatate, H., M. Ohgai, N. Murase, M. Miyake, and N. Suzuki. 1998. Accumulation of fatty acids in Chaetoceros gracilis (Bacillariophyceae) during stationary growth phase. Fisheries Sci., 64(4):578581.

Hu, Q., M. Sommerfeld, E. Jarvis, M. Ghirardi, M. Posewitz, M. Seibert, and A. Darzins. 2008. Microalgal tiacylglycerols as feedstocks for biofuel production: perspectives and advances. The Plant J., 54:621-639.

Mortensen, S.H., K.Y. Boersheim, J.R. Rainuzzo, and G. Knutsen. 1988. Fatty acid and elemental composition of the marine diatom Chaetoceros gracilis schuett. Effects of silicate deprivation, temperature and light intensity. $J$. Exp. Mar. Biol. Ecol., 122:173185.

Leonardos, N. and R.J. Geider. 2004. Responses of elemental and biochemical composition of 
Chaetoceros muelleri to growth under varying light and nitrate: phosphate supply ratios and their influence on critical N:P. Limnology and Oceanography, 49(6):2105-2114.

Lombardi, A.T. and P.J. Wangersky. 1995. Particulate lipid class of three marine phytoplankters Chaetoceros gracilis, Isochrysis galbana (Tahiti) and Dunaliella tertiolecta grown in batch culture. Hidrobiologia, 306:1-6.

Lombardi, A.T. and P.J. Wangersky. 1991. Influence of phosporus and silicon on lipid class production by Chaetoceros gracilis grown in turbidostat cage cultures. Marine Ecology Progress Series, 77:3947.

NREL, 2005. A look back at the U.S. Department of Energy's aquatic species program: biodiesel from algae. National Renewable Energy Laboratory report NREL/TP-58024190.

Nurachman, Z., D.S. Brataningtyas, Hartati, and L.M.G. Panggabean. 2012a. Oil from the tropical marine benthic-Diatom Navicula sp. Applied Biochemistry and Biotechnology, 168(5):1065-1075.

Nurachman, Z., A.S. Hartati, E.E. Anward, G. Novirarin, B. Mangindaan, S. Gandasasmita, and L.M.G. Panggaean. 2012b. Oil productivity of tropical marine datom Thalassiosira sp. Bioresource Technology, 108:240244.

Nurachman, Z., L.M.G. Panggabean, and A. Snita. 2010. Screening of local marine microalgae for biodiesel production. SEAMEO-SEARCA, SEARCA Agriculture and development Paper Series 3. 41p.

Mc. Ginnis, K.M., T.A. Dempster, and M.R. Sommerfeld. 1997.
Characterization of the growth and lipid content of Chaetoceros muelleri. J. of Applied Phycology, 9:19-24.

Panggabean, L.M.G., D.R. Noerdjito, A. Rasyid, and Sutomo. 2012. Biomass and lipid content of Melosira sp. from outdoor mass culture. Oceanology and Limnology in Indonesia, 38(1):105-113.

Panggabean, L.M.G., D.R. Noerdjito, A. Jalius, T. Murniasih, and A. Bayu. 2009a. Biomass and lipid content of seven strain of microalgae grown in laboratory condition. Poster presented Open Science Meeting, Amsterdan, November 2009.

Panggabean, L.M.G., D.R. Noerdjito, T. Murniasih, and A. Bayu. 2009b. Effect of media $F / 2$ and walne on growth and lipid content of Chaetoceros gracilis. Proceeding National Scientific Forum Year VI, Indonesian Oceanology Association (ISOI), Bogor, November 2009. 297-301pp.

Patil, V., K.Q. Tran, and H.R. Giserod. 2008. Toward sustainable production of biofuels from microalgae. International $J$. of Molecular Biotechnology, 9:11881195.

Parish, C.C. and P.J. Wangersky. 1990. Growth and lipid class composition of the marine diatom, Chaetoceros gracilis, in laboratory and mass culture turbidostat. J. of Plankton Research, 12(3):10111021.

Parish, C.C. and P.J. Wangersky. 1987. Particulate and dissolved lipid classes in cultures Phaeodactylum tricornutum grown in cage culture turbidostats with a range of nitrogen supply rates. Marine Ecology Progress Series, 35:119128. 
Round, E.E., R.M. Crawford, and D.G. Mann. 1990. The Diatoms: biology and morphology of the genera. Cambridge University Press. Cambridge. 747p.

Sandra, P., A. Medvedovici, Y. Zhao, and F. David. 2002. Characterization of triglycerides in vegetable oils by silver-ion packed-column supercritical fluid chromatography coupled to mass spectroscopy with atmosphere pressure chemical ionization and coordination ion spray. J. of Chromatography, 974:231-241.

Accepted : March 7, 2013

Revised : 21 Mei 2013

Approved : 20 Juni 2013 